\title{
Structural and Phase Transformations \\ in Contact Zones Al-Ti, Al-Ni and Alloy AMr7 \\ During Plastic Deformation
}

\author{
Michail B. Leskova, \\ Gulsum S. Bektasova ${ }^{\mathrm{b}}$, Artur K. Abkarian', \\ Igor V. Vershinin ${ }^{a}$ and Ludmila I. Kveglis ${ }^{a, b^{*}}$ \\ ${ }^{a}$ Siberian Federal University \\ 79 Svobodny, Krasnoyarsk, 660041, Russia \\ ${ }^{b}$ East Kazakhstan State University \\ 55 Kazakhstan Str., Ust-Kamenogorsk, 070004, \\ The Republic of Kazakhstan
}

Work is devoted research of features of structure formation processes in the contact zone of limited solubility bimetals and alloys subjected to plastic deformation. It is established, that the plastic deformation of limited solubility metals (Al-Ti, Al-Ni), can significantly broaden the scope of their mutual solubility. The appearance of zones of local tensile and compressive stresses (curvature crystal lattice zones) leads to increased solubility, emergence of new phases and redistribution of their composition, reorientation of granular structure.

Keywords: plastic deformation, alloy AMr7, contact zones Al-Ti, Al-Ni, curvature crystal lattice, change solubility, reorientation of granular structure, cluster model.

Citation: Leskov M.B., Bektasova G.S., Abkarian A.K., Vershinin I.V., Kveglis L.I. Structural and phase transformations in contact zones Al-Ti, Al-Ni and alloy AMr7 during plastic deformation, J. Sib. Fed. Univ. Eng. technol., 2017, 10(3), 305-316. DOI: 10.17516/1999-494X-2017-10-3-305-316.

(C) Siberian Federal University. All rights reserved

* Corresponding author E-mail address: kveglis@list.ru 


\title{
Структурные и фазовые превращения
}

\section{в зонах контакта Al-Ti, Al-Ni и сплава AMr7 при пластической деформации}

\author{
М.Б. Лесков ${ }^{a}$, Г.С. Бектасова ${ }^{\sigma}$, \\ А.К. Абкарян ${ }^{\mathrm{a}}$, И.В. Вершинин ${ }^{\mathrm{a}}$, Л.И. Квеглис ${ }^{\mathrm{a}, \bar{\sigma}}$ \\ ${ }^{a}$ Сибирский федеральный университет \\ Россия, 660041, Красноярск, пр. Свободный, 79 \\ ${ }^{6}$ Восточно-Казахстанский государственный университет \\ Республика Казахстан, 070004, \\ Усть-Каменогорск, ул. Казахстан, 55
}

Работа посвящена исследованию особенностей проиессов формирования структуры в зоне контакта биметаллов с ограниченной растворимостью и сплавов, подвергнутых пластической деформации. Установлено, что пластическая деформация металлов с ограниченной растворимостью (Al-Ti, Al-Ni) может значительно расширить область их взаимной растворимости. Появление зон локального растяжения и сжимающих напряжений (зон кривизны кристаллической решетки) приводит к увеличению растворимости, появлению новых фаз и перераспределению их состава, переориентации зернистой структуры.

Ключевые слова: пластическая деформаџия, сплав AMr7, контактные зоны Al-Ti, Al-Ni, кривизна кристаллической решетки, изменение растворимости, переориентация зернистой структуры, кластерная модель.

\section{Introduction}

The study of structural and phase transformations in metals and alloys is one of the important problems of condensed matter physics. Of particular interest are structural and phase transformations in the area of contact insoluble metals subjected to joint plastic deformation [1-7].

The phenomena of expansion mutual solubility with limited solubility metals (Al-Ti, Al-Ni, AMr7) in the area of their contact during the joint plastic deformation are of scientific and practical importance. Formation of new compounds in a stress gradient in soluble (aluminum-magnesium etc.) and practically insoluble metals are important in creating of multilayer composites.

In cold welding by pressure and explosion the deformation defects occurs in the contact zone. For moving these defects, it is necessary that three conditions must be made [8]:

1) the presence of zones normal tensile stresses, creating an increased molar volume where local structural transformation may occur,

2) action in these zones of moment force strains which create local curvature and emergence of nonequilibrium state in the curvature zone,

3) occurrence of new structural states in the curvature zones, which have their own energy spectrum.

The first two conditions correspond to the model proposed by Thompson, which examines the close-Packed layer of atoms in a solid [9].

The third condition proves the possibility of occurrence in the zones of curvature of the crystal lattice of the new structural conditions, like short-range order of displacements and, thereby, causes the 
appearance of the products of the mechanochemical reaction during plastic deformation. The results of the study zone of interaction practically insoluble in each other metals of the system copper-lead was published in the work [10]. According to the equilibrium state diagram "lead-copper" formation of solid solutions and intermediate phases at temperatures up to $600{ }^{\circ} \mathrm{C}$ is impossible. As a result of our work revealed the expansion of the area of solubility of copper in lead and lead in copper, as well as the formation of a new phase $\mathrm{Cu} 3.2 \mathrm{~Pb} 0.8$.

The connection of heterogeneous metals requires the solution of the following problems:

- Identification of structure features processes at the interface in metals having limited solubility: Al-Ti, Al-Ni during the joint plastic deformation;

- Investigation processes formation of structure in different types of plastic deformation soluble in each other metals and alloys (AMr7);

- Developing a model concept and presentation of features structure formation in the areas of contact heterogeneous metals in a stress gradient fields generated by plastic deformation.

The purpose of this work is the investigation of the features structure formation processes in the area of contact a heterogeneous metals and alloys under joint plastic deformation.

\section{Materials and research methods of the experiment.}

For research were used the following materials: Al-Ti, Al-Ni, AMr7.

AxioObserver.ZI optical microscope. Scanning electron microscopy methods (HITACHI TM1000, JSM-7001F).

The composition of the alloys was controlled methods of spectral, X-ray fluorescence analysis using X-ray analyzer SwiftED-TM EDX.

The phase composition of these samples were determined by X-ray diffraction diffractometer "Bruker" using copper radiation.

In this study materials were formed according to the technology described elsewhere [11-13]. Aluminum and titanium foils, aluminum and nickel foils were enclosed in titanium shells with outer diameter of $30 \mathrm{~mm}$ and height of $10 \mathrm{~mm}$. Sintering was carried out using a Labox-1575 spark plasma sintering (SPS) [12] machine in Lavrentiev Institute of Hydrodynamics (SB RAS). All the samples were sintered at $830^{\circ} \mathrm{C}$ under the pressure of $40 \mathrm{MPa}$. Sintering duration equaled to 10 minutes.

Experiments on the plastic deformation of the samples: samples AMr7 was done at the forging and stamping machine stamp C-812A. Used modes single and sequential bumps.

Chemical composition of the investigated samples was determined using the prefix of the INCA by scanning electronic microscope JSM-6480LV, where they considered amendments to the standard sample and serial number of the item. Phase analysis was performed on BRUKER x-ray diffractometer, which used the filtration of the $\beta$ - radiation.

\section{Results and discussion.}

Figure 1 show the image of the sample Ti-Al-Ni obtained: an optical light microscope; and scanning electron microscopy. The image in the scanning electron microscope from fragment of the sample TiAl-Ni surface was received from area, marked with a red rectangle, is represented in a Fig. 1. Figure 2 show the characteristic X-ray spectrum is obtained from the region indicated by dotted rectangle

$$
-307-
$$


(shown in Fig. 1b, Spectrum 1). Figure 3 show the X-ray diffraction picture in Cu-Kó irradiation from area was represented in Fig. 1.

The tetragonal phase A12Ti was previously experimentally obtained in [14]. The lattice parameters of this phase were theoretically calculated in [15] to a temperature of $0{ }^{\circ} \mathrm{C}$. The results of our experimental data is shown in Table 1, the lattice parameters are obtained, where $\mathrm{a}=3,971 \AA$ and $=24,313 \AA$. These data are in good agreement with the results of [14].

Titanium can be exist in phase with hcp and fcc lattice, the most striking diffraction reflexes of which are coincide. Titanium phase with an fcc lattice with parameters a $=4,013 \AA$, was detected for the thin film state in [16], and confirmed theoretically in [15]. Formation of titanium phase FCC can be explained by the structure formation in the conditions of plastic deformation under dynamic loads

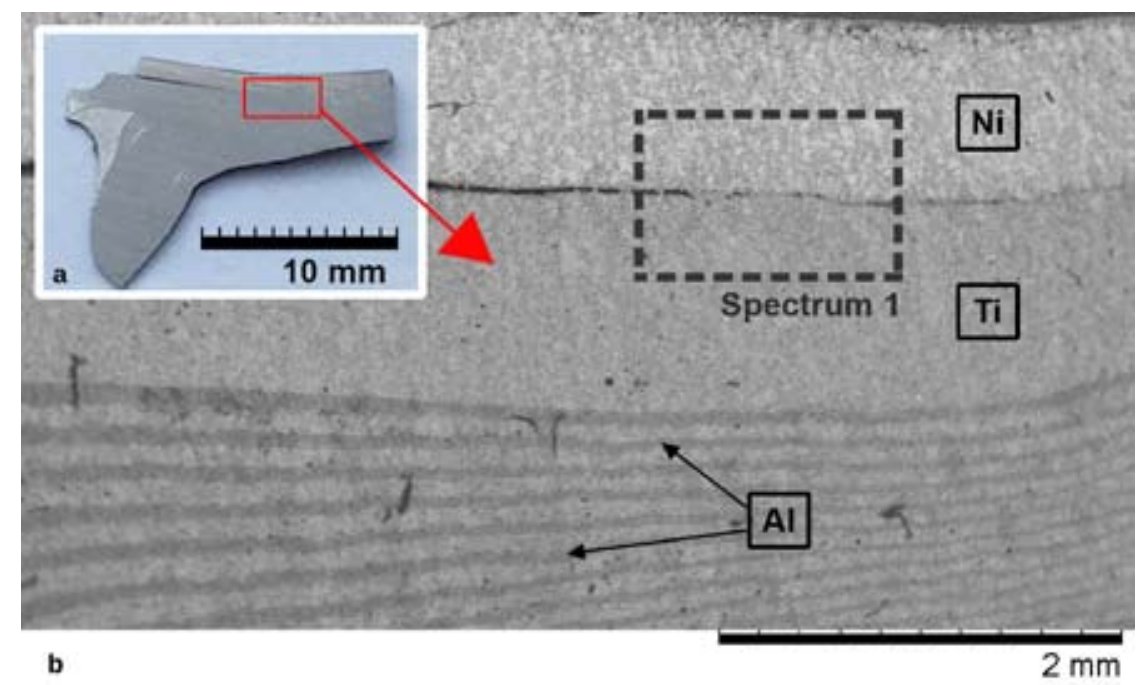

Fig. 1. The image of the sample Ti-Al-Ni obtained: $a-$ an optical light microscope; $b-$ scanning electron microscopy

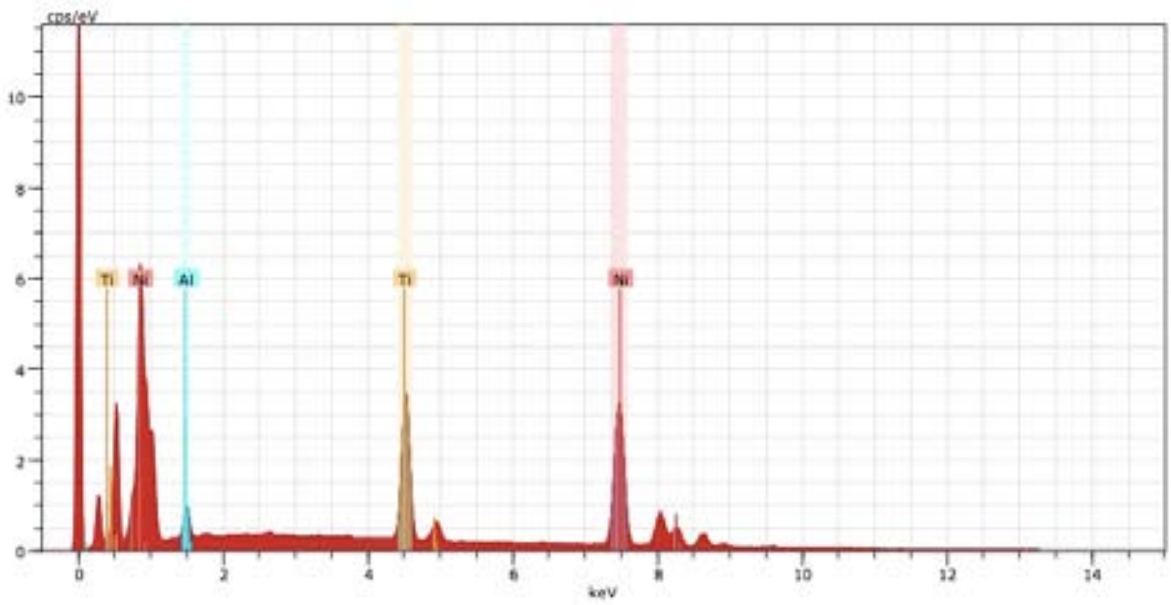

Fig. 2. The characteristic X-ray spectrum obtained from the region rectangle shown in Fig. 1b, Spectrum 1 


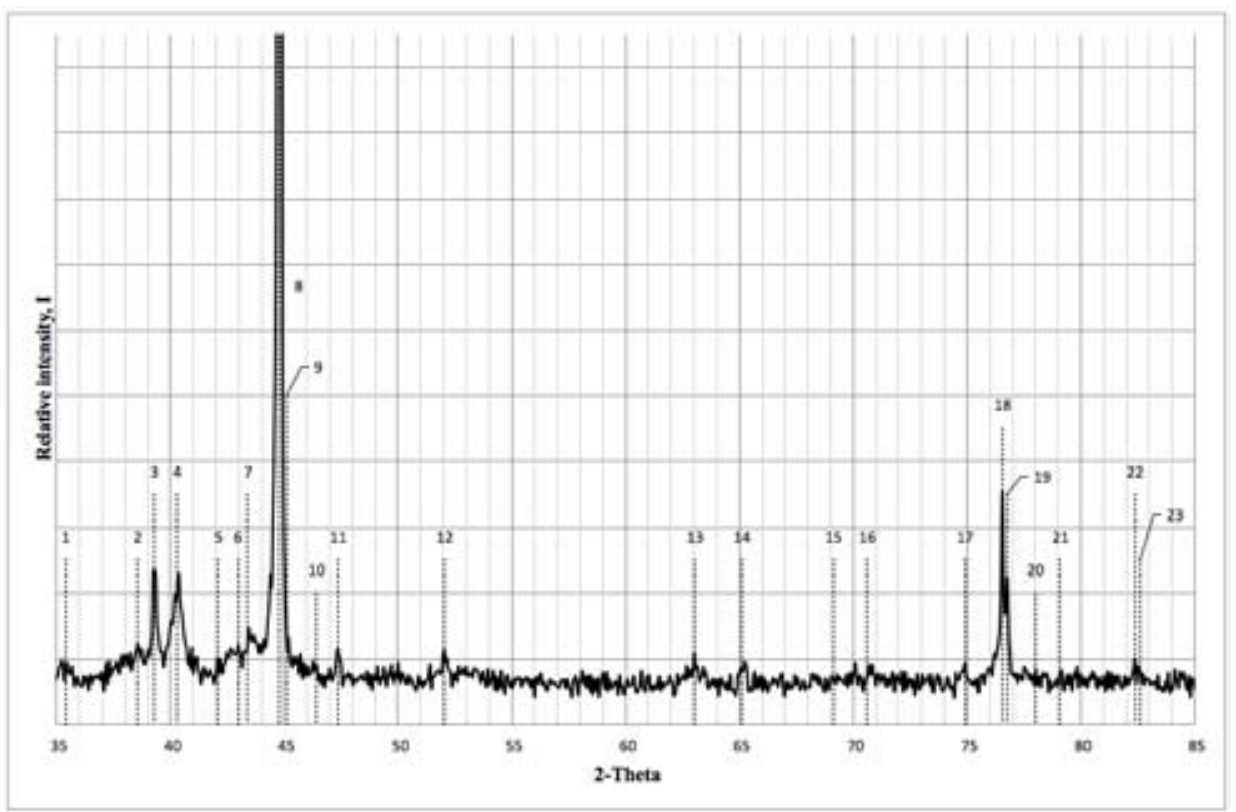

Fig. 3. The spectrum of X-ray diffraction composite spark plasma sintering Ti-Al-Ni and its interpretation (Table 1)

by using the cluster model, illustrated in Fig. 4 [17]. Figure 4a shows that the lattice is formed FCC if octahedra surrounded by tetrahedra. HCP lattice (Fig. 4b) represents the alternating pairs of tetrahedra and octahedra, linked by common triangular faces. Aluminium has an fcc lattice with the parameter $\mathrm{a}=3,98 \AA$ that near to $\mathrm{a}=4,013 \AA$ - parameters fcc lattice Titanium. As a result we can see solid solutions $\mathrm{Al}$ and $\mathrm{Ti}$ in wide area. 111 diffraction reflex aluminum 3 titanium phase is almost coincide with the 002 reflex of titanium HCP

On the X-ray diffraction, there are traces of compounds titanium and nickel, their appearance can see from point of view cluster model. From this it follows that the transformation of the fcc $-\mathrm{hcp}$ can occur due to shift and rotation of the tetrahedra and octahedra clusters and this process requires a minimum energy in the close-packed layers of atoms. Such clustering mechanism of structural transformation is confirmed by theoretical calculations in [15]. Clusters of fcc and hep lattices are identical, which is confirmed by the results shown in Table 1: interplanar distance d111 fcc lattice are equal to interplanar distances $\mathrm{d} 002 \mathrm{hcp}$ lattice.

On Fig. 5 we can see that plastic deformation initiates the self-organization of microstructure on the meso-level - texture formation. In different condition may be formed textures with different zone axis: 1 - less pressure, it formed texture with zone axis [200]; 2 - more pressure, it formed texture with zone axis [220].

In our previous works [20] structural self-organization initiated by plastic deformation was found. The recrystallization of polycrystalline material can be initiated by plastic deformation. As a result, fractal (dendritic) structures generated. Such structures we have observed during plastic deformation AMr7 alloy. The results of studies AMr7 during plastic deformation by steam-hammer shock loading presented on the Fig. 6. We can see the image dendrites AMr7 alloy surface in a 
Table 1. Interpretation of X-ray diffraction spectrum presented in Fig. 2

\begin{tabular}{|c|c|c|c|c|c|c|c|c|c|c|c|c|}
\hline \multirow{2}{*}{$\begin{array}{l}\text { № } \\
\text { line }\end{array}$} & \multicolumn{2}{|c|}{$\begin{array}{l}\text { Tetragonal } \\
\mathrm{Al}_{2} \mathrm{Ti}\end{array}$} & \multicolumn{2}{|c|}{ Al FCC } & \multicolumn{2}{|c|}{ Ti HCP } & \multicolumn{2}{|c|}{$\begin{array}{c}\text { Tetragonal } \\
\mathrm{Al}_{3} \mathrm{Ti}\end{array}$} & \multicolumn{2}{|c|}{ Ni FCC } & \multirow{2}{*}{$\begin{array}{c}\mathrm{d}, \AA \\
\text { experim. }\end{array}$} & \multirow{2}{*}{$\begin{array}{l}\text { The angle } \\
2 \text { Theta }^{\circ}\end{array}$} \\
\hline & hkl & $\mathrm{d}, \mathrm{tabl}$ & hkl & $\mathrm{d}, \mathrm{tabl}$ & hkl & $\mathrm{d}, \mathrm{tabl}$ & hkl & d, tabl & hkl & $\mathrm{d}, \mathrm{tabl}$ & & \\
\hline 1 & & & & & 100 & 2,54 & $111^{*}$ & & & & 2,526 & 35,5 \\
\hline 2 & & & 111 & 2,33 & 002 & 2,34 & & & & & 2,328 & 38,7 \\
\hline 3 & & & & & & & 202 & 2,289 & & & 2,291 & 39,2 \\
\hline 4 & & & & & 101 & 2,23 & & & & & 2,246 & 40,2 \\
\hline 5 & & & & & & & 004 & 2,142 & & & 2,144 & 42,1 \\
\hline 6 & 002 & & & & & & & & & & 2,110 & 42,8 \\
\hline 7 & & & & & & & & & & & 2,077 & 43,6 \\
\hline 8 & & & & & & & & & 111 & 2,038 & 2,023 & 44,9 \\
\hline 9 & & & 200 & 2,02 & & & & & & & 2,001 & 45,3 \\
\hline 10 & 200 & 1,985 & & & & & & & & & 1,981 & 45,8 \\
\hline 11 & & & & & & & 220 & 1,913 & & & 1,917 & 47,5 \\
\hline 12 & & & & & & & 222 & 1,752 & 200 & 1,766 & 1,756 & 52,1 \\
\hline 13 & & & & & 110 & 1,47 & 224 & 1,471 & & & 1,473 & 63 \\
\hline 14 & & & 220 & 1,43 & & & 006 & 1,429 & & & 1,432 & 65,1 \\
\hline 15 & & & & & 103 & 1,33 & & & & & 1,359 & 69,1 \\
\hline 16 & & & & & & & $222 *$ & & & & 1,331 & 70,8 \\
\hline 17 & & & & & 200 & 1,274 & & & & & 1,267 & 74,9 \\
\hline 18 & & & & & 112 & 1,248 & & & & & 1,245 & 76,6 \\
\hline 19 & & & & & 201 & 1,230 & & & 220 & 1,230 & 1,235 & 77,2 \\
\hline 20 & & & 311 & 1,219 & & & & & & & 1,221 & 78 \\
\hline 21 & 311 & & & & & & & & & & 1,209 & 79,1 \\
\hline 22 & & & & & & & & & & & 1,173 & 82,2 \\
\hline 23 & 222 & & & & & & & & & & 1,166 & 82,6 \\
\hline
\end{tabular}

* - the calculation of the parameter $\mathrm{C}$.

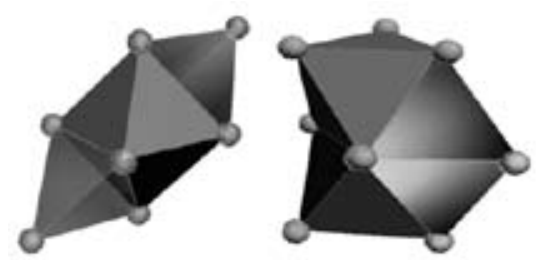

Fig. 4. Cluster model: on the left - for the fcc lattice 2 tetrahedra and 1 octahedra clusters; on the right - for hcp lattice 2 tetrahedra and 2 octahedra clusters

scanning electron microscope. Dendrite structure was formed after shock loading alloy surface subjected to 6 shocks. On Fig. 7 is presented x-ray diffraction from surface AMr7 alloy after dynamic loading: I - initial state, II - 1 shock, III - 3 Shocks; IV - 6 shocks; It is formed texture with zone axis [220]. 


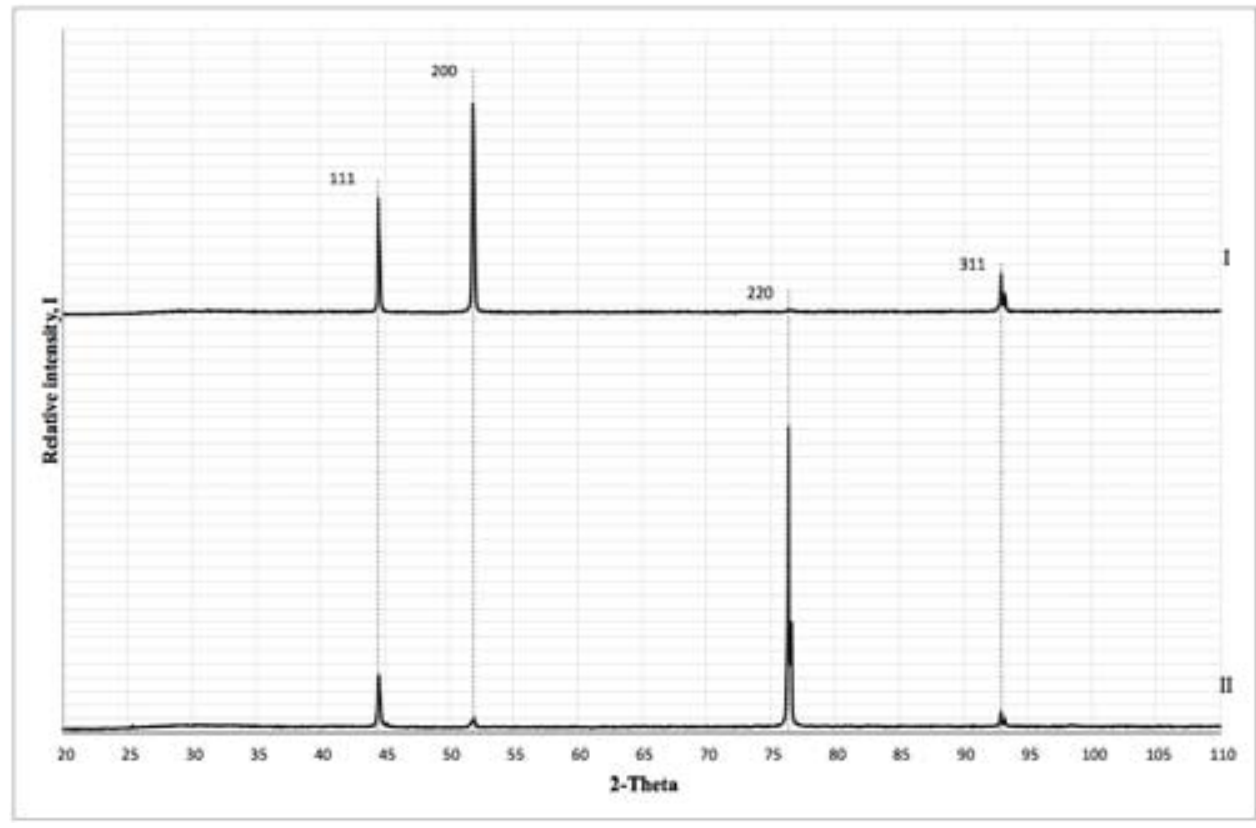

Fig. 5. X-ray diffraction from surface Ni-Al alloy after dynamic loading; the zone where the sample at the SPS sintering got: 1 - less pressure, it formed texture with zone axis [200]; 2 - more pressure, it formed texture with zone axis [220]

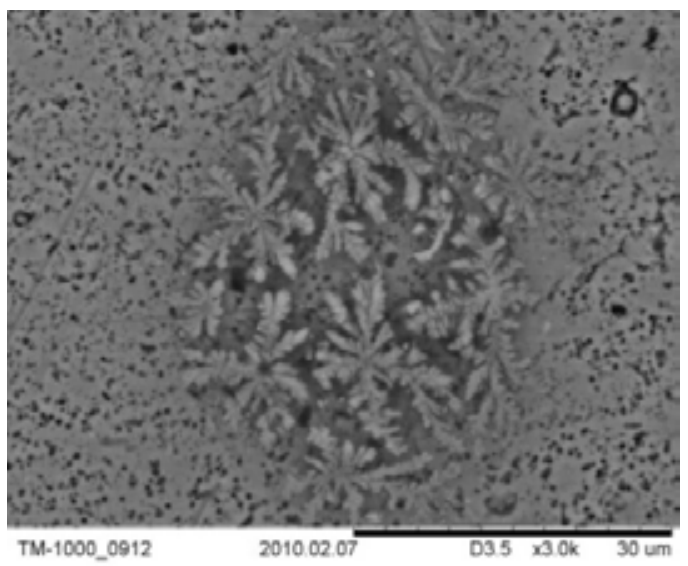

Fig. 6. Image dendrites AMr7 alloy surface in a scanning electron microscope (SEM) alloy surface subjected to 6 shocks

Fractal structures are realized through the bifurcation point, or the point of a split when the load reaches of the critical sign. This is a condition in which the system becomes unstable with respect to plastic deformation creating lattice curvature.

Thus in the different conditions of plastic deformation bifurcation formed interatomic positions in areas of the crystal lattice curvature, which contributed to the emergence and growth of dendrites.

The term "Interatomic bifurcation structural states" (IBSS) was introduced by V.E. Panin [21]. 


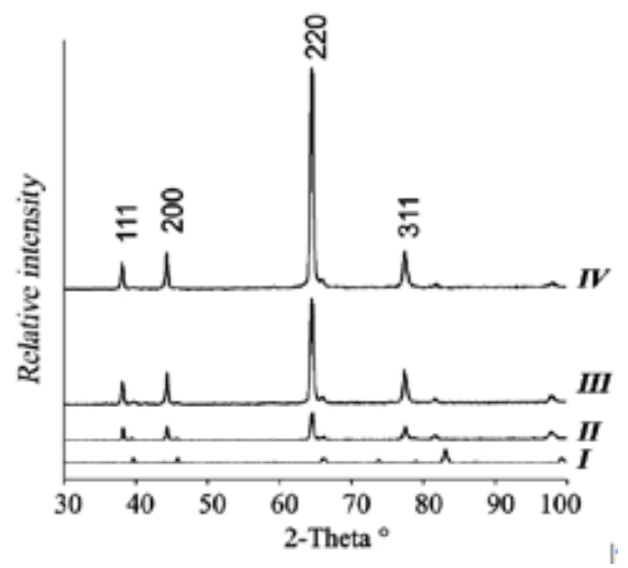

Fig. 7. X-ray diffraction from surface AMr7 alloy after dynamic loading: I - initial state, II - 1 shock, III - 3 Shocks; IV - 6 shocks; It is formed texture with zone axis [220]
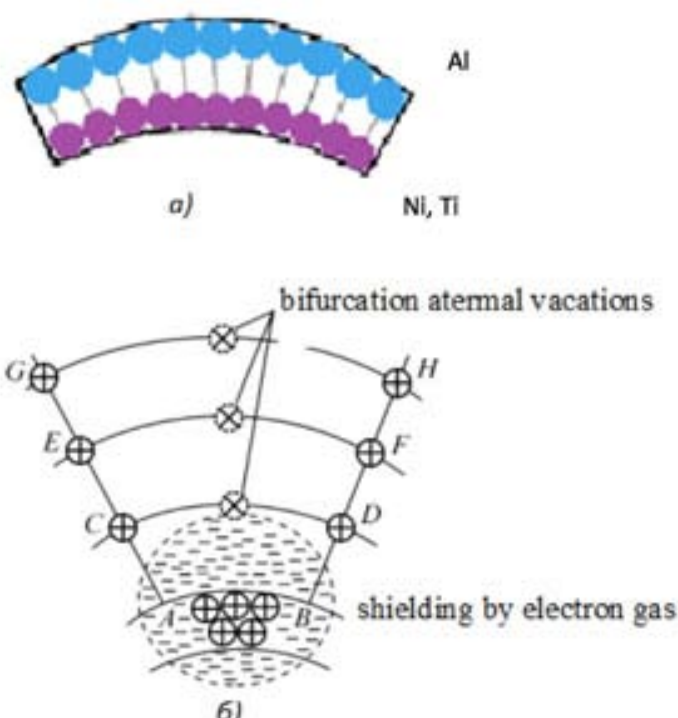

6)

Fig. 8. Interatomic bifurcation structures states (IBSS)

On the Fig. 8 represented interatomic bifurcation structures states (IBSS) driving in areas local curvature lattice:

a - curvature zone at the interface of different metals: Al-Ti, Al-Ni after plastic deformation;

$\mathrm{b}$ - generation of interatomic bifurcation structures states [21] shielding by electron gas of atoms group is creating nanoparticle.

Inhomogeneous distribution of atomic position in the areas of local curvature crystal lattice resulting to increase mutual solubility.

At the interface of 2 heterogeneous environments under the influence of an external load occurs modulation of tensile and compressive normal and shear stresses. This modulation strain creates 
a zone of the crystal lattice curvature at the interface, which has a increase or decrease in the interatomic distances. Supercritical states lead to the formation of athermal vacancies bifurcation. IBSS arise here that are not in a stable translation invariant crystal. There is a redistribution of the electron gas in the areas of curvature, which leads to the nanoparticles formation. IBSS can increase the mutual solubility of insoluble metals to form metastable phases and atomically ordered structures in a short time.

Energy diagrams states of material subjected to plastic deformation are represented in the work [16]. If the energy coming from the outside is sufficient to exceed the activation energy for the formation of these compounds, chemical bonds will break and elements will form ions. This excited states of atoms have a time of life about $10^{-13} \mathrm{~s}$. As a result of switching of the chemical bonds the reaction product will have a significantly lower energy. The reaction is exothermic.

The dependence of thermodynamic potential of Gibbs from the molar volume. It is need to take into account the existence local bands of a hydrostatic tension various scales in which been appearance of different defective structures [21].

Zhurkov [22] In equation (1) is determined during the product lifetime of metal alloys depending on the temperature, mechanical loads, as well as the relaxation of the activation energy which is related to the chemical composition of the alloy:

$$
\tau=\tau_{0} \exp \frac{U_{0}-\gamma \delta}{R T}
$$

where $\mathrm{U}_{0}$ - the initial activation energy $(\mathrm{Ea}) ; \gamma$ - the volume of excited atoms $; \delta$ - strain; $\tau_{0}-$ the pre-exponential factor equal to the period of the order of magnitude of the thermal vibrations of the atoms; $\mathrm{T}$ - temperature; $\mathrm{R}=\mathrm{kN}_{\mathrm{A}}$; where $\mathrm{N}_{\mathrm{A}}-$ Avogadro's number; $\mathrm{k}-$ is Boltzmann's constant.

In the work of Makarov S.V. [23] the second term in formula 1 is divided into 2 parts: static and dynamic. Static and dynamic load create different effects on the change in the activation energy of $\mathrm{U}_{0}$

Acknowledgments. The authors thank, Mali V.I. (Russian Academy of Sciences Lavrentyev Institute of Hydrodynamics) for help with the experiment and discussion.

\section{Conclusions}

1. It was found that the joint plastic deformation of limited solubility metals (Al-Ni, Al-Ti) can significantly expand the scope of their mutual solubility.

2. In areas the localization of plastic deformation under shock and under tensile loads occur mechanochemical reactions. The products of these reactions are detected.

3. The formation of particles enriched alloy components at the bottom of craters in the cracks are explained as a result of dynamic rotations are organized on the micro, meso- and macro-scale levels.

4. Features of structure in terms of strain gradient fields generated by plastic deformation associated with the formation of interatomic bifurcation structures states (IBSS). The emergence of bands local tensile normal stress causes: increased solubility, the emergence of new phases, adjusting their composition. 


\section{References}

[1] Рыбин В.В. Большие пластические деформации и разрушение металлов. М.: Металлургия, 1986. 224 с. [Rybin V.V. Large plastic deformation and fracture of metals. М.: Metallurgy, 1986. 224 p. (in Russian)]

[2] Рыбин В.В., Ушанова Э.А., Кузьмин С.В., Лысак В.И. Природа пластического течения металлов в приконтактной зоне при сварке взрывом. Журнал технической физики, 2011, 37 (23), 26-33. [Rybin V.V., Ushanova E.A., Kuzmin S.V., Lisak V.I. Nature of plastic flow of metal in the contact zone with the explosion welding. Technical Physics, 2011, 37 (23), 26-33. (in Russian)]

[3] Леган М.А. Дис. Градиентные критерийразрушения взоне концентрации напряжений. док. технических наук. Новосибирск, 2005. 300 с. [Legan M.A. Dis. Gradient criterion of destruction in the area of stress concentration. Doc. technical Sciences. Novosibirsk, 2005. 300 p. (in Russian)]

[4] Болдырев В.В. Экспериментальные методы в механохимии твердых неорганических веществ. Новосибирск.: Наука, 1983.65 c. [Boldyrev V.V. Experimentalmethods in Mechanochemistry inorganic solids. Novosibirsk.: Science, 1983. 65 p. (in Russian)]

[5] Айнбиндер С.Б. Холодная сварка металлов. Рига: Изд-во АН Латв. ССР, 1957. 162 с. [Ainbinder S.B. Cold welding metal. Riga: Publishing House of the Academy of Sciences of Latvia. SSR, 1957. 162 p. (in Russian)]

[6] Гриценко А.Ф., Шестаков А.И., Ермоленко О.Е. Холодная сварка давлением разнородных металлов. Сварочное производство, 1963, 2, 32-33. [Gritsenko A.F., Shestakov A.I., Ermolenko O.E. Cold pressure welding of dissimilar metals. Welding production, 1963, 2, 32-33. (in Russian)]

[7] Пеев А.П. Дис. Разработка технологических прочессов изготовления сваркой взрывом медно-алюминиевых элементов токоподводящих узлов для предприятий энергетики и электрометаллургии. кан. технических наук. Волгоград, 2001. 147 c. [Peev A.P. Dis. Development of technological processes of manufacture of explosion welding copper and aluminum elements for the current supply units companies Energy and electrometallurgy. Ch. Technical Sciences. Volgograd, 2001. 147 p. (in Russian)]

[8]Панин B.Е., Егорушкин В.Е. Солитоны кривизны как обобщенные волновые структурные носители пластической деформации и разрушения. Физическая мезомеханика. 2013, 16 (3), 7-26. [Panin V.E., Egorushkin V.E. Solitons curvature as structural supports generalized wave of plastic deformation and fracture. Physical mesomechanics. 2013, 16 (3), 7-26. (in Russian)]

[9] Томпсон Д.М. Неустойчивости и катастрофы в науке и технике. М.: Мир, 1985. 289 c. [Thompson M.D. Instability and catastrophes in science and technology. M.: Mir, 1985. 289 p. (in Russian)]

[10] Абкарян А.К., Абылкалыкова Р.Б., Падар В.А., Носков Ф.М., Калитова А.А. и т.д. Особенности структурообразования в системе свинец - медь при интенсивных динамических нагрузках. Журнал Сибирский федеральный университет. Техника и технологии, 2013, 6, 818-827. [Abkaryan A.K., Abylkalykova R.B., Padar V.A., Noskov F.M., Kalitova A.A. etc. Features of structure in the system lead - copper at intensive dynamic loads. Journal of Siberian Federal University. Engineering technology, 2013, 6, 818-827. (in Russian)]

[11] Lazurenko D.V., Ogneva T., Lozhkin V., TerentievD., Kashimbetova A., Mali V.I., Anisimov A.G. Relation between the structure and mechanical properties of Ti-Al-Based MIL composites 
and a thickness of initial metallic components used for their producing. International conference on mechanical engineering, automation and control systems (MEACS): proc., Tomsk, 2015, 4.

[12] Lazurenko D.V., Mali V.I., Bataev I.A., Thoemmes A., Bataev A.A., Popelukh A.I., Anisimov A.G., Belousova N.S. Metal-Intermetallic Laminate Ti-A13Ti Composites Produced by Spark Plasma Sintering of Titanium and Aluminum Foils Enclosed in Titanium Shells. Metallurgical and Materials Transactions A: Physical Metallurgy and Materials Science, 2015, 46 (9), 4326-4334.

[13] Lazurenko D.V., Mali V.I., Anisimov A.G., Yartsev P.S., Lagereva D.I., Shevtsova L.I. The structural particularities of multilayered metal-intermetallic composites fabricated by the spark plasma sintering technology. Advanced Materials Research, 2014, 1040, 800-804.

[14] Braun J., Ellner M. X-ray high-temperature in situ investigation of the aluminide TiAl2 (HfGa2 type). Journal of Alloys and Compounds, 2000, 309, 118.

[15] Ghosh G., Asta M. First-principles calculation of structural energetics of Al-TM (TM = Ti, Zr, Hf) intermetallics. Acta Materialia, 2005, 53, 3225-3252.

[16] Квеглис Л.И., Пынько В.Г., Корчмарь В.С. Эпитаксиальный рост пленок Ti, Mn, Cr, V на подложках LiF и MgO. Физика твердого тела, 1971, 13 (11), 3341. [Kveglis L.I., Pynko V.G., Korchmar V.S. Epitaxial growth of films of $\mathrm{Ti}, \mathrm{Mn}, \mathrm{Cr}, \mathrm{V}$ and $\mathrm{LiF}$ on $\mathrm{MgO}$ substrates. Solid State Physics, 1971, 13 (11), 3341. (in Russian)]

[17] Квеглис Л.И., Носков Ф.М., Волочаев М.Н., Джес А.В. Мартенситные превращения в никелиде титана через промежуточную фазу с ГЦК-решеткой. Физическая мезомеханика, 2016, 19 (2), 100-107. [Kveglis L.I., Noskov F.M., Volochaev M.N., Jess A.V. Martensitic transformations in NiTi through an intermediate phase with fcc. Physical mesomechanics, 2016, 19 (2), 100-107. (in Russian)]

[18] Сигинцов Н.В., Юшков В.Н., Ходыев М.С. Структура, текстура и упрочнение гидро прессованной стали 03Х11Н10М2Т. Физика Металлов и Металловедение, 1986, 61(6), 1178-1181. [Sigintsov N.V., Yushkov V.N., Hodiev M.S. Structure, texture and hardening hydraulic pressed steel 03H11N10M2T. Physics of Metals and Metallurgy, 1986, 61 (6), 1178-1181. (in Russian)]

[19] Рыбин В.В., Золоторевский Н.Ю., Ушанова Э.А. Фрагментация кристаллов при наличии деформационного двойникования и динамической рекристаллизации. Физика Металлов и Металловедение, 2015, 116 (7), 1-16. [Rybin V.V., Zolotorevskii N.Y., Ushanova E.A. The fragmentation of the crystals in the presence of deformation twinning and dynamic recrystallization. Physics of Metals and Metal Science, 2015, 116 (7), 1-16. (in Russian)]

[20] Квеглис Л.И., Абылкалыкова Р.Б., Тажибаева Г.Б., Садибеков А.Б. Трансляционноротационный механизм массопереноса при механической обработке поверхности сплава 67КН5Б. В сб. материалов Межд. симпозиума «Наноматериаль для защиты промышленных и подземных конструкиий» и ХІ Межд. конф. «Физика твердого тела». Усть-Каменогорск, 2010, 344-348. [Kveglis L.I., Abylkalykova R.B., Tazhibaeva G.B., Sadibekov A.B. Translation-rotation mechanism of mass transfer during machining 67KN5B alloy surface. In Proc. Between materials. Symposium "Nanomaterials for the protection of industrial and underground constructions" and XI Int. Conf. "Solid state physics". Ust-Kamenogorsk, 2010, 344-348. (in Russian)]

[21] Панин В.Е., Егорушкин В.Е. Наноструктурные состояния в твердых телах. Физика Металлов и Металловедение, 2010, 110(5), 487-496 [Panin V.E., Egorushkin V.E. Nanostructured state in solids. Physics of Metals and Metal Science, 2010, 110 (5), 487-496 (in Russian)] 
[22] Журков С.Н., Санфирова Т.П. Связь между прочностью и ползучестью металлов и сплавов. Журнал технической физики, 1958, 28, 1719-1726. [Zhurkov S.N., Sanfirova T.P. The relationship between creep resistance and of metals and alloys. Technical Physics, 1958, 28, 1719-1726. (in Russian)]

[23] Плотников, В.А. Макаров С.В. Акустическая эмиссия при высокотемпературной деформации алюминия. Деформация и разрушение материалов, 2005, 3, 27-31 [Plotnikov V.A., Makarov S.V. Acoustic emission at high temperature deformation of aluminum. Deformation and fracture of materials, 2005, 3, 27-31 (in Russian)] 